\title{
PENGEMBANGAN BAHAN AJAR GEOGRAFI SMA/MA KELAS XII PADA KOMPETENSI DASAR POLA KERUANGAN DESA DAN KOTA DENGAN MODEL DICK AND CAREY
}

\author{
Onik Farida Ni'matullah \\ Dosen Pendidikan Geografi Universitas Kanjuruhan Malang
}

\begin{abstract}
Abstrak
Orientasi penyediaan buku teks di berbagai sekolah di Indonesia saat ini, terutama buku teks Geografi, hanya difokuskan pada segi kuantitas. Fakta menunjukkan bahwa penyediaan buku penunjang pembelajaran Geografi di sekolah hanya mempertimbangkan segi proporsi jumlah siswa dengan jumlah buku yang tersedia. Dari segi kualitas, masih banyak materi pada buku pelajaran Geografi yang sebenarnya menunjukan kelemahan yang mendasar: pertama, teks Geografi "mengabaikan" aspek kebenaran bahasa, fakta/data, konsep, generalisasi, kebenaran penyajian gambar. Hasil validasi pada ahli materi pelajaran, bahan ajar berada dalam kategori baik (71\%). Hasil uji coba pada ahli rancangan pembelajaran, bahan ajar berada dalam kategori baik (71\%). Hasil uji coba ahli bahasa berada dalam kategori sangat baik (91\%), tetapi masih ada beberapa kesalahan pengetikan dan pemenggalan kata. Hasil uji coba lapangan pada siswa, bahan ajar berada dalam kategori baik (80\%), sedangkan hasil uji coba lapangan pada guru, bahan ajar berada dalam kategori baik (82\%). Pengembangan selanjutnya disarankan, yaitu: (a) pengembangan bahan ajar Geografi tidak terbatas hanya pada kelas XII semester dua pada kompetensi dasar menganalisis pola keruangan desa dan kota. Untuk menghasilkan produk bahan ajar secara utuh sebaiknya dikembangkan untuk dua semester (semester satu dan semester dua), (b) uji coba bahan ajar ini terbatas di Kota Malang. Untuk menghasilkan bahan ajar yang berlaku secara nasional sebaiknya dilakukan uji coba lapangan dengan mengambil sampel yang diperluas di wilayah Indonesia.
\end{abstract}

Kata Kunci: bahan ajar Geografi.

\begin{abstract}
The orientation of text book supply in many school in Indonesia, especially for geography is only focused on quantity. In fact the supply of book to support geography learning in school only considered with the proportion of students' number. In quality aspect, there are still many books show the basic weaknesses namely "ignoring" language truth aspect, fact/data, concept, generalization, picture performance and material acceptance. Therefore it needs for a problem solution alternative by developing or improving text book oriented in those aspect. Based on the result of validation on material expert, text book is in good category (71\%). The result of validation on learning design, text book is in good category $(71 \%)$. The result of language text expert test, text book is in very good category (91\%). But there still many mistyping and incorrect pause. The result of test on the students, text book is in very good category (80\%). While the result of test on teacher, text book is in very good category (82\%). Usage suggestion: (a) for teacher and students, must pay attention to the usage instruction on the initial part of the text book, (b) before learning this text book, read and comprehend the abstract which represent the available mind mapping.
\end{abstract}

\section{Keyword: geography text book.}

Orientasi penyediaan buku teks di berbagai sekolah di Indonesia saat ini, terutama buku teks Geografi, hanya difokuskan pada segi kuantitas. Fakta menunjukkan bahwa penyediaan buku penunjang pembelajaran Geografi di sekolah hanya mempertimbangkan segi proporsi jumlah siswa dengan jumlah buku yang tersedia. Dari segi kualitas, masih banyak materi pada buku pelajaran Geografi yang sebenarnya menunjukan kelemahan yang mendasar: pertama, teks Geografi 
"mengabaikan" aspek kebenaran bahasa, fakta/data, konsep, generalisasi, kebenaran penyajian gambar, serta ketercernaan materi berdasarkan Badan Standar Nasional Pendidikan (BSNP) yang mengutamakan tiga komponen utama yakni; 1) memenuhi komponen kebahasaan, 2) komponen isi, 3) komponen Geografi, yakni menyangkut aspek objek studi material dalam hal interaksi, interrelasi dan interdependensi. Oleh karena itu, diperlukan alternatif pemecahan masalah dengan mengembangkan buku teks yang mengarah pada perbaikan dari tiap aspek tersebut.

Produk bahan ajar yang dikembangkan berdasarkan kaidah keilmuan Geografi dan kurikulum KTSP melalui modifikasi model Dick dan Carey (2001). Prosedur pengembangan model ini terdiri atas sepuluh langkah, namun dalam pengembangan ini hanya dilakukan lima langkah, yakni: (1) mengidentifikasi standar kompetensi, kompetensi dasar dan indikator berdasarkan konsep BNSP, (2) melakukan analisis materi pelajaran, (3) menyusun dan penulisan bahan ajar, (4) mevalidasi bahan ajar, (5) merevisi produk akhir hasil pengembangan bahan ajar. Oleh karena itu, tujuan pengembangan adalah menghasilkan bahan ajar Geografi untuk SMA/MA Kelas XII Semester II pada Kompetensi Dasar Pola Keruangan Desa dan Kota yang sesuai dengan standar isi, kaidah keilmuan Geografi, dan kaidah penulisan bahan ajar dengan model Dick and Carey.

\section{Spesifikasi Produk yang Dihasilkan}

Spesifikasi produk pengembangan bahan ajar ini adalah:

1. Materi bahan ajar disesuaikan standar kompetensi dan kompetensi dasar (kurikulum 2006) bidang studi
Geografi untuk SMA/MA kelas XII Semester II.

2. Pada awal bab dilengkapi dengan peta konsep.

3. Memuat konsep-konsep konkrit dan abstrak, konsep konkrit disajikan dengan gambar (tidak didefinisikan), sedang konsep abstrak ditulis dalam bentuk definisi istilah.

4. Paparan atau deskripsi obyek material dan obyek formal disajikan secara simultan.

5. Data atau fakta ditampilkan lebih aktual dan kontekstual.

6. Bahan ajar yang dihasilkan merupakan hasil kajian berbagai bahan pustaka baik elektronik maupun pustaka Geografi yang relevan dan divalidasi oleh ahli di bidangnya.

\section{Pentingnya Pengembangan}

Pengembangan bahan ajar Geografi untuk SMA Kelas XII Semester II pada Kompetensi Dasar Pola Keruangan Desa dan Kota penting dilakukan untuk:

1. Sebagai salah satu sumber belajar yang dapat mengoptimalkan proses pembelajaran sehingga hasil belajar dapat meningkat.

2. Bagi siswa, pengembangan bahan ajar ini penting karena dapat digunakan sebagai salah satu sumber belajar yang diharapkan dapat memudahkan dalam proses belajar baik secara individual maupun melalui bimbingan guru.

3. Bagi guru, pengembangan bahan ajar dengan model Dick dan Carey ini dapat memfasilitasi proses belajar siswa sehingga diharapkan dapat memberikan arahan bagi guru dalam membimbing siswa untuk mencapai standar kompetensi lulusan. 
4. Memperbaiki kesalahan konsep, gambar, data, objek formal dan materi yang ada pada Kompetensi Dasar Pola Keruangan Desa dan Kota.

5. Bagi guru dan siswa, dapat mempermudah memahami materi/isi secara sistematis karena bahan ajar yang dikembangkan memperhatikan konsistensi isi pada masing-masing sub topik dan dilengkapi dengan fakta dan data yang akurat dan kontekstual.

\section{Asumsi dan Keterbatasan Pengembangan}

Berikut disajikan beberapa asumsi yang melandasi pengembangan bahan ajar:

1. Bahan ajar yang berisi data/fakta yang aktual, kontekstual, tampilan gambar yg menarik, dan tambahan karikatur kartun dapat meningkatkan minat belajar siswa dan dapat menghapus kesan bahwa Geografi merupakan pelajaran yang membosankan.

2. Bahan ajar yang baik dan mudah dimengerti, menjadikan siswa lebih mudah dalam menyerap materi pelajaran.

Bahan ajar mata pelajaran Geografi yang dikembangkan terbatas pada beberapa hal.

1. Pengembangan bahan ajar dengan menggunakan model Dick and Carey, tetapi dimodifikasi/disederhanakan dari 10 langkah menjadi 5 langkah.

2. Langkah pengembangan bahan ajar ini hanya sampai pada tahapan formatif.

3. Pengembangan bahan ajar Geografi terbatas hanya pada siswa SMA kelas XII semester II.

4. Produk bahan ajar mata pelajaran Geografi hanya mencakup satu standar kompetensi, yaitu "Pola Keruanan Desa dan Kota".
5. Uji coba hasil pengembangan dilakukan pada SMA Muhammadiyah I Malang dan SMA Islam Al-Hikmah Tajinan Malang.

Pengembangan adalah proses penerjemahan spesifikasi desain ke dalam bentuk fisik (Seels \& Richey, 1994). Kawasan pengembangan mencakup banyak variasi teknologi yang digunakan dalam pembelajaran. Walaupun demikian, tidak berarti lepas dari teori dan praktek yang berhubungan dengan belajar dan desain. Misalnya, fokus kegiatan dalam kawasan pengembangan, tidak terlepas dari teori desain pesan, teori belajar, dan teori pemprosesan informasi. Kawasan pengembangan tidak hanya terdiri dari perangkat keras pembelajaran, melainkan juga mencakup perangkat lunaknya, bahan-bahan visual dan audio, serta program atau paket yang merupakan perpaduan berbagai bagian. Hal ini sejalan dengan pendapat Anglin (1991) bahwa pengembangan pembelajaran adalah pendekatan sistem yang mencoba untuk mengaplikasikan secara ilmiah prinsipprinsip perencanaan, desain, kreasi, penerapan, dan evaluasi keefektifan dan keefisienan pembelajaran.

Dalam kawasan pengembangan terdapat keterkaitan yang kompleks antara keempat kategori teknologi yang meliputi cetak, teknologi audio visual, teknologi berasaskan komputer, dan teknologi terpadu dengan teori yang mendorong, baik desain pesan maupun strategi pembelajaran. Pada dasarnya kawasan pengembangan dapat dijelaskan dengan adanya: (1) pesan yang didorong oleh isi, (2) strategi pembelajaran, dan (3) manifestasi fisik dari teknologi perangkat keras, perangkat lunak dan bahan pembelajaran (Seels \& richey, 1994). 
Teknologi merupakan tenaga penggerak dari kawasan pengembangan. Berangkat dari asumsi ini, dapat dirumuskan dan dijelaskan berbagai jenis media pembelajaran dan karakteristiknya. Proses ini tidak dapat diartikan hanya sebagai suatu pengkategorisasian, tetapi sebagai elaborasi dari karakteristik prinsip-prinsip teori dan desain yang dimanfaatkan oleh teknologi.

Kawasan pengembangan oleh Seels dan Richey (1994) diorganisasikan menjadi empat kategori, yaitu:

1. Teknologi Cetak, merupakan cara memproduksi atau menyampaikan bahan-bahan seperti buku-buku dan bahan-bahan visual yang statis, terutama melalui percetakan mekanis atau fotografis.

2. Teknologi Audiovisual, merupakan cara memproduksi dan menyampaikan bahan dengan menggunakan peralatan mekanis dan elektronik untuk menyajikan pesan-pesan audio dan visual.

3. Teknologi Berbasis Komputer, merupakan cara-cara memproduksi dan menyampaikan bahan dengan menggunakan perangkat yang bersumber pada mikroprosesor.

4. Teknologi Terpadu, merupakan cara untuk memproduksi dan menyampaikan bahan dengan memadukan beberapa jenis media yang dikendalikan melalui komputer.

\section{Metode Penelitian}

Dalam pengembangan bahan ajar ini, prosedur pengembangan dilakukan melalui 5 tahap, yaitu:

1. Identifikasi standar kompetensi, kompetensi dasar dan indikator berdasarkan konsep BSNP.
2. Analisis materi:

Langkah-langkah analisis materi pelajaran pada pengembangan bahan ajar ini meliputi:

a. Dalam mengembangkan materi pembelajaran ini, terlebih dahulu dilakukan analisis materi. Analisis materi ditinjau berdasarkan kebenaran isi/ materi, kebahasaan, penyajian, dan komponen lainnya. Jika komponen-komponen tersebut telah dianalisis dan ditemukan permasalahan, maka perlu dilakukan pengembangan produk yang representatif bagi pengetahuan siswa.

b. Mengkaji berbagai sumber terkait dengan kebutuhan materi pelajaran untuk mencapai standar kompetensi.

c. Menyusun kompetensi dasar sesuai dengan tata urut kompetensi dasar dan indikator.

3. Tahap pengembangan dan penulisan bahan ajar, bahan ajar memuat komponen pembelajaran yang meliputi: a) judul bab, b) rumusan standar kompetensi, kompetensi dasar dan indikator, c) peta konsep, d) uraian materi, e) tugas dan latihan, f) rangkuman kompetensi dasar, g) test akhir bab, dan h) sumber pendukung.

4. Validasi bahan ajar

Tinjauan ahli dan uji coba merupakan langkah pembelajaran pada proses evaluasi formatif. Evaluasi ini merupakan proses dalam penggunaan informasi untuk dijadikan dasar pengambilan keputusan dalam rangka meningkatkan kualitas produk yang dikembangkan berupa bahan ajar.

Evaluasi formatif ini dilakukan setelah pengembangan bahan ajar yang masih 
dalam bentuk draf selesai dibuat. Evaluasi ini dibuat dengan maksud mengumpulkan data yang digunakan untuk penyempurnaan bahan ajar tersebut. Pada tahap ini dilakukan validasi bahan ajar, meliputi tanggapan ahli materi pelajaran, ahli bahasa, ahli rancangan pembelajaran, dan uji coba lapangan. Keterangan berupa saran atau masukan yang didapat melalui angket yang diberikan kepada para ahli dan hasil uji coba lapangan digunakan dalam menyempurnakan produk bahan ajar.

5. Revisi dan produk akhir hasil pengembangan bahan ajar

Tahap ini merupakan tahap terakhir dari tahap pengembangan bahan ajar mata pelajaran. Data yang diperoleh dari penilaian formatif disimpulkan dan diuraikan sebagai usaha untuk mengenali kesulitan siswa menyerap kompetensi dasar/isi bahan ajar yang dikembangkan. Produk pengembangan direvisi dengan memperhatikan saran dan kritikan dari para ahli, siswa, dan guru pada saat validasi dan uji coba dilaksanakan. Misalnya siswa memiliki kesulitan memahami salah satu definisi, maka yang diperhatikan adalah apakah karena kesalahan konsep atau karena kurangnya uraian penjelasan terhadap definisi yang dimaksud, juga bisa jadi karena konsep tersebut membutuhkan gambar/foto.

\section{Hasil Penelitian dan Pembahasan}

Pengembangan buku teks merupakan bagian dari teknologi pembelajaran dan salah satu alternatif untuk meningkatkan hasil belajar siswa (output). Selain cara belajar, buku teks yang baik juga dapat meningkatkan hasil belajar siswa. Antara penerapan model-model pembelajaran dengan pengembangan buku teks sebenarnya mempunyai tujuan yang sama, yaitu untuk mempermudah dalam penyampaian materi pelajaran. Perbedaan antara keduanya adalah, penerapan model-model pembelajaran merupakan langkah terorganisir untuk menyampaikan materi pelajaran secara langsung, sedangkan buku teks merupakan sarana untuk mengorganisir materi pelajaran dan menyampaikannya secara tidak langsung. Dengan buku teks yang berkualitas dan mudah dimengerti, dapat menjadikan siswa lebih mudah menyerap materi.

Berdasarkan hasil validasi pada ahli materi pelajaran, bahan ajar berada dalam kategori baik (71\%). Hasil uji coba pada ahli rancangan pembelajaran, bahan ajar berada dalam kategori baik (71\%). Hasil uji coba ahli bahasa berada dalam kategori sangat baik (91\%), tetapi masih ada beberapa kesalahan pengetikan dan pemenggalan kata. Hasil uji coba lapangan pada siswa, bahan ajar berada dalam kategori baik (80\%), sedangkan hasil uji coba lapangan pada guru, bahan ajar berada dalam kategori baik (82\%).

Berdasarkan analisis data yang diperoleh dari angket uji coba lapangan kepada siswa dan guru menujukkan bahwa bahan ajar berada pada kualifikasi baik. Walaupun demikian, masih ada beberapa saran baik dari siswa maupun guru yang tetap mendapat perhatian sebagai bahan untuk penyempurnaan bahan ajar. Saran dan komentar dari guru dan siswa berupa: latihan soal diperbanyak dan gambar kurang besar.

Kandungan isi dari bahan ajar ini ditulis berdasarkan data dan fakta yang terbaru, aktual dan konseptual. Di samping fakta dan data juga dilengkapi dengan gambar-gambar yang menunjukkan fakta dan data tersebut, sehingga siswa dapat berkomunikasi langsung dengan bahan ajar. 
Lebih lanjut, untuk membuat siswa lebih ingin mengetahui isi bahan ajar ini maka dalam komponen isi dilengkapi dengan tugas kepada siswa untuk mencari informasi yang lebih banyak melalui internet atau referensi lainnya. Paparan atau deskripsi obyek material dan obyek formal disajikan secara simultan. Untuk membuat materi bahan ajar ini berkualitas, maka dilakukan validasi ahli materi pelajaran. Berdasarkan hasil validasi ahli materi pelajaran, materi yang dimuat dalam bahan ajar ini telah layak untuk diuji cobakan, namun perlu direvisi berdasarkan hasil komentar dan tanggapan dalam angket validasi.

Untuk membuat aspek kebahasaan tidak menyimpang dari kaidah bahasa yang ditentukan (sesuai dengan EYD dalam kaidah penulisan bahasa Indonesia), maka dilakukan validasi ahli bahasa. Setelah dilakukan validasi ahli bahasa ternyata ditemukan banyak kesalahan baik dari aspek kosakata, tanda baca, kesalahan penggunaan huruf kapital dan huruf kecil, dan kategori kesalahan lainnya. Berdasarkan hasil validasi ahli bahasa dilakukan perbaikan secara serius dengan terus berkoordinasi dengan ahli bahasa. Dengan demikian bahan ajar yang disusun ini telah melalui validasi ahli bahasa sehingga dari aspek kebahasaan sudah layak untuk dibaca dan diuji cobakan.

Bahan ajar ini disajikan dengan memperhatikan konsep materinya. Jika konsep yang ada menyangkut hal-hal yang bersifat konkrit maka penyajiannya menggunakan gambar dengan sedikit penjelasan.

\section{Simpulan}

Saran desiminasi, antara lain: (a) mengadakan seminar skala regional bahkan nasional tentang pengembangan bahan ajar, khususnya bahan ajar Geografi untuk SMA/MA, (b) diperkenalkan kepada forumforum Musyawarah Guru Mata Pelajaran (MGMP) Geografi, dan (c) dimuat dalam suatu rubrik atau kolom penulisan buku di alamat suatu website.

Pengembangan selanjutnya disarankan, yaitu: (a) pengembangan bahan ajar Geografi tidak terbatas hanya pada kelas XII semester dua pada kompetensi dasar menganalisis pola keruangan desa dan kota. Untuk menghasilkan produk bahan ajar secara utuh sebaiknya dikembangkan untuk dua semester (semester satu dan semester dua), (b) uji coba bahan ajar ini terbatas di Kota Malang. Untuk menghasilkan bahan ajar yang berlaku secara nasional sebaiknya dilakukan uji coba lapangan dengan mengambil sampel yang diperluas di wilayah Indonesia, (c) untuk menghasilkan produk bahan ajar yang dikembangkan secara lebih berkualitas dibutuhkan waktu penelitian dan pengembangan yang relatif lama (multy years). Hal tersebut perlu dilakukan sebab bahan ajar yang dikembangkan diharapkan dapat digunakan oleh siswa seluruh Indonesia dengan kualitas yang lebih baik dan yang lebih penting adalah mendorong siswa untuk mau membaca bahan ajar, (d) dalam uji coba pengembangan bahan ajar ini tidak sampai memperhatikan pengaruh bahan ajar hasil pengembangan terhadap hasil belajar siswa. Untuk memperoleh hasil yang lebih berkualitas pada pengembangan buku ini sebaiknya dilakukan tes kepada siswa sebelum dan sesudah membaca buku hasil pengembangan ini. 


\section{Pustaka Rujukan}

Alwasilah, A. C. 2000. Politik Bahasa dan Pendidikan. Bandung. Remaja Rosdakarya.

Astina, I N. G. 1997. Pengembangan Paket Pembelajaran Teknik Penyajian Minuman I Dengan Menerapkan Rancangan Model Dick \& Carey. Tesis tidak diterbitkan. Malang: Program Pascasarjana UM.

BSNP. 2006. Petunjuk Teknis Pengembangan Silabus Mata Pelajaran Geografi SMA. Jakarta: Departemen Pendidikan Nasional.

BSNP. 2006. Instrumen Tahap II Penilaian Buku Teks Pelajaran Geografi SMA/MA. Jakarta:Departemen Pendidikan Nasional. Dick, W \& Carey, L. 2001. The Sistemetic Design Of Instruction. Illionois: Scott, Foresman and Company.

Seels, B. B \& Richey, R. C. 1994. Instructional Technology: The Definition And Domain Of The Field. Washington DC: AECT.

Soepena, Ps. 1997. Bagaimana Buku Mampu Bertahan Samapai Abad Komputer. Buletin Pusat Perbukuan, Departemen Pendidikan dan Kebudayaan. No. 3, Juli. Hal. 31-33.

Sudrajat, A. 2008. Sumber Belajar Untuk Mengefektifkan Pembelajaran Siswa. (http://www.akhmadsudrajat.com, diakses 7 Maret 2009).

Sugiyono, 2008. Metode Penelitian Pendidikan, Pendekatan Kualitatif, Kuantitatif, dan $R \& D$. Alfabeta Bandung.

Sumarmi. dkk. 2001. Pencitraan Buku teks Geografi SMU Berdasarkan Kurikulum 1994. Malang: Lemlit Universitas Negeri Malang.
Suparman, A. 1997. Desain Instruksional. Jakarta: Direktorat Pendidikan Tinggi, Departemen Pendidikan dan Kebudayaan.

Tillena, H. 1983. Web Teaching: "Sequencing of Subject Matter in Relation to Prior Knowledge of Pupil". Instructional Science. Vol. 12, hal. 321332

Widhiyanto, G. 1997. Informasi Buku dan Perbukuan. Majalah Ilmiah Kampus Ungu, Maret, hal. 98-104.

Winataputra, U. S. 1989. Konsep dan Masalah Pengajaran Ilmu Pengetahuan Sosial di Sekolah Menengah. Jakarta: Dirjen Dikti Depdikbud. 